\title{
The public-private sector wage differential in the UK: evidence from longitudinal employer-employee data
}

Article

Accepted Version

Creative Commons: Attribution-Noncommercial-No Derivative Works 4.0

Singleton, C. (2019) The public-private sector wage differential in the UK: evidence from longitudinal employer-employee data. Economics Letters, 174. pp. 109-113. ISSN 0165-1765 doi: https://doi.org/10.1016/j.econlet.2018.11.005 Available at https://centaur.reading.ac.uk/80309/

It is advisable to refer to the publisher's version if you intend to cite from the work. See Guidance on citing.

To link to this article DOI: http://dx.doi.org/10.1016/j.econlet.2018.11.005

Publisher: Elsevier

All outputs in CentAUR are protected by Intellectual Property Rights law, including copyright law. Copyright and IPR is retained by the creators or other copyright holders. Terms and conditions for use of this material are defined in the End User Agreement.

$\underline{\text { www.reading.ac.uk/centaur }}$ 
Central Archive at the University of Reading

Reading's research outputs online 


\title{
The public-private sector wage differential in the UK: Evidence from longitudinal employer-employee data
}

\author{
Carl Singleton* \\ School of Economics, The University of Edinburgh, \\ 31 Buccleuch Place, Edinburgh, EH8 9JT, UK
}

Declarations of interest: none

\begin{abstract}
If fiscal policy exerts pressure on public services, then attention often falls on the public-private sector wage differential. Estimated with longitudinal employer-employee data for the years 2002-16 in the United Kingdom, among men there was no significant public sector wage premium. However, women received an average $4 \%$ premium compared with working in private sector firms.
\end{abstract}

Keywords: public sector premium, firm-specific wages, gender JEL codes: J31, J38, J45

${ }^{*}$ Permanent address: Department of Economics, University of Reading, Edith Morley, Whiteknights Campus, Reading, RG6 6UB, UK, c.a.singleton@reading.ac.uk 


\section{Introduction}

In 2010 the UK government imposed caps on nominal wage increases throughout the public sector. This policy was relaxed in 2017 as real wage growth in the private sector recovered (see Cribb (2017) for a summary). The UK is not the only country to restrain public sector pay while attempting fiscal consolidation. Such policies are commonly justified by the supposed existence of large public sector wage premiums which are not allocative, due to the bargaining power of trade unions (e.g. France in 2017 and the United States in 2019). However, pay-setting restraint could affect the ability of organisations to hire and retain employees, having implications for services provision. Wage policies in the public sector can also affect the level and volatility of unemployment in the wider economy (e.g. Gomes, 2015). Therefore, it is important that public sector wage premiums are measured robustly.

The unobserved quality of workers across sectors is likely endogenous to any wage differential (Nickell and Quintini, 2002), biasing ordinary least squares (OLS) estimates from cross-sectional data of the public sector premium. Privatisation has been used as a 'natural experiment' to circumvent this (e.g. Haskel and Szymanski, 1993). Estimates were later improved using longitudinal household survey data, which could address selection on worker unobservables, typically finding larger public sector premiums (e.g. Disney and Gosling, 1998). However, estimates from these data will also be confounded if worker mobility between sectors is related to differences in other wage-relevant employer fixed characteristics. For example, Chatterji et al. (2011) used UK cross-sectional employer-employee data to suggest that gender and sectoral wage differences are related to certain workplace characteristics. These included performance-related pay and family-friendly working, which were more common in the private and public sectors, respectively.

Using longitudinal employer-employee panel data and estimating gender-specific Abowd et al. (1999) (henceforth AKM) wage equations, this article revisits the UK public sector premium.

\section{Method}

Let there be $i=1, \ldots, N$ workers, $j=1, \ldots, J$ firms, $t=1, \ldots, T$ years, $T_{i}$ years per worker and $N^{*}=\sum_{i} T_{i}$ total observations. The AKM-type wage equations are given by:

$$
w_{i t}=\alpha_{i}+\phi_{J(i t)}^{G(i)}+\mathbf{x}_{i t}^{\prime} \boldsymbol{\beta}^{G(i)}+\varepsilon_{i t},
$$

where $w_{i t}$ is the log real hourly wage. $\mathbf{x}_{i t}$ is a vector of time-varying observable worker, job or firm characteristics. Firm fixed effects are given by $\phi_{J(i t)}^{G(i)}$, where $J(i t)=j$ indicates 
the firm employing worker $i$ in year $t$. Similarly, $G(i)=g \in\{$ Male,Female $\}$ indicates gender. The remaining heterogeneity is in the residual, $\varepsilon_{i t}$.

Equation (1) can be estimated using least squares with a strict exogeneity assumption:

$$
E_{i t}\left[\varepsilon_{i t} \mid \mathbf{x}_{i t}, \alpha_{i}, \phi_{J(i t)}^{G(i)}, G(i)\right]=0 .
$$

Estimates of the firm fixed effects will be biased if employees switch firms according to some component of $\varepsilon_{i t}$, such as transitory shocks to firm-wide or worker-firm match-specific effects. However, Jewell et al. (2018) find this exogenous mobility assumption is not obviously rejected in these UK data. ${ }^{1}$

The worker fixed effects are transferable, affecting wages wherever and whenever an employee works, and in whatever job. The firm fixed effects measure relative wage premiums, which employees receive upon moving between firms. Estimates of these effects are only comparable within mobility groups, i.e. connected sets of workers and firms (Abowd et al., 2002). Therefore, the analysis focuses on the largest identified mobility groups of men or women in the panel dataset.

Using estimates of Equation (1), the male or female public sector premium is defined as:

$$
\widehat{\delta}_{A K M}^{g}=E_{i t}\left[\widehat{\phi}_{J(i t)}^{G(i)} \mid G(i), J(i t) \in \text { Public }\right]-E_{i t}\left[\widehat{\phi}_{J(i t)}^{G(i)} \mid G(i), J(i t) \notin \text { Public }\right],
$$

where Public is the set of employers not in the private sector. This measures the expected log hourly wage gain for an employee who switches from the private to the public sector, keeping the characteristics in $\mathbf{x}_{i t}$ unchanged.

Compare Equation (1) with the reduced form version:

$$
w_{i t}=\alpha_{i}+\operatorname{Public}_{i t} \delta_{W F E}^{G(i)}+\mathbf{x}_{i t}^{\prime} \boldsymbol{\beta}^{G(i)}+r_{i t}
$$

where Public $c_{i t}=\mathbf{1}_{J(i t) \in \text { Public }}$ and $r_{i t}$ is the composite error term. Least squares estimates of the public sector premium from Equation (2), $\widehat{\delta}_{W F E}^{g}$, will be unbiased compared with $\widehat{\delta}_{A K M}^{g}$ only if the following orthogonality condition holds:

$$
E_{i t}\left[\left(r_{i t}-\bar{r}_{i}\right)\left(P u b_{i t}-\overline{P u b}_{i}\right) \mid G(i)\right]=0 \text {, }
$$

where bars over variables represent time averages. This will not hold when individuals move between sectors systematically from high to low wage employers, or vice versa.

\footnotetext{
${ }^{1}$ See Card et al. (2013) and Card et al. (2018) for evidence in favour of this assumption for Germany and Portugal, respectively.
} 


\section{Data}

The data are from the Annual Survey of Hours and Earnings (ASHE), 2002-16. This is drawn from administrative records each April by the Office for National Statistics (ONS). It is a panel of employees without attrition, where each year gives an approximate $1 \%$ random and representative sample of UK employees. The linked employers in these data are enterprises. ${ }^{2}$

The analysis looks at the hourly wage rate according to employer payrolls, excluding overtime. Wages are deflated to 2002 prices using April values of the Consumer Price Index (CPI). ${ }^{3}$ Only prime-working-age employees, aged 25-64, who have non-missing records of earnings and hours are considered. Observations with 1-100 basic paid weekly hours are dropped, as are non-main jobs, those at a trainee or an apprentice level, and any jobs incurring a loss of pay in the reference period for whatever reason. Unless stated otherwise, $\mathbf{x}_{i t}$ contains the following job characteristics: squared and cubed employee age, cubic polynomials for tenure and employer size (number of employees), whether a job is part-time (thirty hours or less), and 3-digit (92 categories) occupations. $\mathbf{x}_{i t}$ also includes year fixed effects. The private or public status of an employer is from administrative records. ${ }^{4}$ See Jewell et al. (2018) for further details on how this dataset can be constructed from ASHE cross-sections.

The estimation sample contains only person-year observations which are in the largest male or female mobility groups. This has around $80-90 \%$ of ASHE observations each year, and is generally UK representative, though firm size is marginally higher than in the population. Table 1 gives brief sample descriptive statistics.

\section{Results}

Estimating Equation (1) in the years 2002-16, the public sector premiums are 0.0 and $3.8 \mathrm{log}$ points for male and female hourly wages, respectively (Table 1, row 3). Estimates accounting for only worker fixed effects are larger, being 2.9 and 4.5 $\log$ points (row 2). This suggests that, when workers move from the private to the public sector, they tend to do so from relatively low wage employers within the former to relatively high wage employers within the latter. Pooled OLS estimates (row 1) are consistent with previous results from the UK, that individuals with a low

\footnotetext{
2"An Enterprise can be defined as ... an organisational unit producing goods or services, which benefits from a certain degree of autonomy in decision-making ... An enterprise carries out one or more activities at one or more locations." ONS. In the public sector, schools, hospitals, government departments, the British Broadcasting Corporation etc. are enterprises.

${ }^{3}$ Accessed from UK National Statistics, 24/4/2017.

${ }^{4}$ ASHE contains the tax authority classification: private companies, sole proprietors and partnerships are classified as private sector. Public corporations \& nationalised industries, central government, local authorities, non-profit bodies or mutual associations are classified as public sector.
} 
permanent wage component disproportionately work in the public sector, especially among men. Rows 4-6 of Table 1 present estimates without occupation controls in the wage equations. Comparing the pooled OLS estimates (rows $1 \& 4$ ), the differences in employee occupations between the public and private sectors account for a large part of the average wage differences between the sectors. The estimated public sector premiums from the wage models with worker and firm fixed effects are greater when occupation controls are left out (rows 5-6). This suggests that part of the average wage gain experienced by workers who switch from the private to the public sector is due to related wage gains from them also changing occupations at the same time.

Figure 1 shows kernel density estimates over employee-year observations of the estimated firm fixed wage effects, by gender, and comparing sectors. These effects have tighter variance in the public sector. If working in the private sector, then men and women had similar tendencies to work in very high wage firms (> 15 log points). However, there is a stark gender difference in so far as women were more likely to work in very low wage firms in the private sector $(<-15 \log$ points).

Public sector employers range from schools to financial services regulators. Table 2 presents estimates comparable to Table 1, row 3 for subgroups of public sector enterprises. In local authorities, the wage premium compared with the private sector was around $2 \%$ for both men and women. In central government, men received a 3\% wage penalty, whereas women received a $5 \%$ premium. The largest premiums were for employees in public corporations and nationalised industries (e.g. National Rail and the $\mathrm{BBC})$.

Figure 2 shows estimates of $\delta_{W F E}^{g}$ and $\delta_{A K M}^{g}$ from the largest mobility groups of men and women in rolling 7-year windows, along with shares of employment in the public sector. The wage premium for women was stable over 2002-16. For men the premium increased by over 6 log points in this period. This was despite the public sector wage moderation policies of government since 2010.

\section{Conclusion}

Previous estimates of the UK public-private sector wage differential have not addressed unobserved worker and unobserved firm heterogeneity. After doing so, the estimated average public sector premium received by men between 2002 and 2016 men was zero. The value among women was $4 \%$.

The importance of firms in frictional wage dispersion has been increasingly studied in recent years (e.g. Card et al., 2018). This article showcases a valuable source of linked employer-employee panel data from the UK, which adds to sources from other 
countries already extensively studied. Future research should use this to revisit what the determinants of other UK wage differentials are.

\section{Acknowledgements}

This work was based on the Annual Survey of Hours and Earnings Dataset (Crown copyright 2017), which is funded, collected and deposited by the Office for National Statistics under secure access conditions with the UK Data Service (UKDS) (SN:6689). The use of these data does not imply endorsement of the data owner or the UKDS in relation to the interpretation or analysis of the data. Comments from colleagues at The University of Edinburgh are gratefully acknowledged.

Funding: This work was supported by the Economic and Social Research Council (UK) under Grant No. ES/J500136/1.

\section{References}

Abowd, J., R. H. Creecy, and F. Kramarz. 2002. "Computing Person and Firm Effects Using Linked Longitudinal Employer-Employee Data.” Longitudinal Employer-Household Dynamics Technical Papers, Center for Economic Studies, U.S. Census Bureau.

Abowd, J., F. Kramarz, and D. Margolis. 1999. "High Wage Workers and High Wage Firms." Econometrica, 67(2): 251-334.

Card, D., A. R. Cardoso, J. Heining, and P. Kline. 2018. "Firms and Labor Market Inequality: Evidence and Some Theory." Journal of Labor Economics, 36(S1): S13 - S70.

Card, D., J. Heining, and P. Kline. 2013. "Workplace Heterogeneity and the Rise of West German Wage Inequality.” The Quarterly Journal of Economics, 128(3): 967-1015.

Chatterji, M., K. Mumford, and P. Smith. 2011. "The public-private sector gender wage differential in Britain: evidence from matched employee-workplace data." Applied Economics, 43(26): 3819-3833.

Cribb, J. 2017. "Public sector pay:still time for restraint?.” IFS Briefing Note BN216, Institute for Fiscal Studies.

Disney, R., and A. Gosling. 1998. "Does it pay to work in the public sector?." Fiscal Studies, 19(4): 347-374.

Gomes, P. 2015. “Optimal Public Sector Wages.” The Economic Journal, 125(587): 1425-1451.

Haskel, J., and S. Szymanski. 1993. "Privatization, Liberalization, Wages and Employment: Theory and Evidence for the UK." Economica, 60(238): 161-81.

Jewell, S., G. Razzu, and C. Singleton. 2018. "Who Works for Whom and the UK Gender Pay Gap?.” ESE Discussion Papers, Edinburgh School of Economics, University of Edinburgh.

Nickell, S., and G. Quintini. 2002. "The Consequences of The Decline in Public Sector Pay in Britain: A Little Bit of Evidence." The Economic Journal, 112(477): F107-F118.

Office for National Statistics. 2017. "Annual Survey of Hours and Earnings, 1997-2016: Secure Access. [data collection]." 9th Edition SN: 6689, UK Data Service. 
TABLE 1: Estimates of the UK public sector log wage premium and sample descriptives, 2002-16

\begin{tabular}{|c|c|c|}
\hline & Male & Female \\
\hline \multicolumn{3}{|l|}{ With 3-digit occ. controls (preferred): } \\
\hline 1. Pooled OLS $-\widehat{\delta}_{O L S}$ & $\begin{array}{c}-0.020^{* * *} \\
(0.003)\end{array}$ & $\begin{array}{c}0.040^{* * *} \\
(0.002)\end{array}$ \\
\hline 2. Worker fixed effects $-\widehat{\delta}_{W F E}$ & $\begin{array}{c}0.029^{* * *} \\
(0.004)\end{array}$ & $\begin{array}{c}0.045^{* * *} \\
(0.002)\end{array}$ \\
\hline 3. Worker \& firm fixed effects $-\widehat{\delta}_{A K M}$ & $\begin{array}{c}0.000 \\
(0.001)\end{array}$ & $\begin{array}{c}0.038^{* * *} \\
(0.001)\end{array}$ \\
\hline \multicolumn{3}{|l|}{ Without occ. controls: } \\
\hline 4. Pooled OLS $-\widehat{\delta}_{O L S}$ & $\begin{array}{c}0.103^{* * *} \\
(0.003)\end{array}$ & $\begin{array}{c}0.181^{* * *} \\
(0.003)\end{array}$ \\
\hline 5. Worker fixed effects - $\widehat{\delta}_{W F E}$ & $\begin{array}{c}0.044^{* * *} \\
(0.004)\end{array}$ & $\begin{array}{c}0.057^{* * *} \\
(0.003)\end{array}$ \\
\hline 6. Worker \& firm fixed effects $-\widehat{\delta}_{A K M}$ & $\begin{array}{c}0.013^{* * *} \\
(0.001)\end{array}$ & $\begin{array}{c}0.046^{* * *} \\
(0.001)\end{array}$ \\
\hline \multicolumn{3}{|l|}{ Mean (st. dev.) log hourly wage: } \\
\hline Public & $\begin{array}{c}2.52 \\
(0.48)\end{array}$ & $\begin{array}{c}2.31 \\
(0.46)\end{array}$ \\
\hline Private & $\begin{array}{c}2.40 \\
(0.57)\end{array}$ & $\begin{array}{c}2.10 \\
(0.49)\end{array}$ \\
\hline Share in public sector & 0.30 & 0.53 \\
\hline \multicolumn{3}{|l|}{ Share full-time (>30 hours): } \\
\hline Public & 0.88 & 0.57 \\
\hline Private & 0.93 & 0.61 \\
\hline \multicolumn{3}{|l|}{ Mean firm size (000s of employees): } \\
\hline Public & 28.9 & 16.4 \\
\hline Private & 14.7 & 25.8 \\
\hline$N^{*}:$ person-year obs. & 797,835 & 858,136 \\
\hline$N$ : Persons & 119,424 & 126,980 \\
\hline Public sector firms & 5,607 & 9,690 \\
\hline Private sector firms & 43,137 & 38,517 \\
\hline
\end{tabular}

$£ 2002$. Standard errors (in parentheses) estimated robustly using person clusters. Alternative standard errors estimated using firm-year clusters were of similar magnitude and did not affect inference; ${ }^{* * *}$ statistically significant at the $1 \%$ level, two-sided tests. 
TABLE 2: Estimates of the log wage premium relative to private sector for types of public enterprise, 2002-16

\begin{tabular}{ccc}
\hline & Male & Female \\
\hline Central government: & & \\
Share of all UK employees & 0.09 & 0.19 \\
Mean log hourly wage diff. & 0.155 & 0.262 \\
Wage Premium - $\widehat{\delta}_{A K M}$ & $-0.027^{* * *}$ & $0.055^{* * *}$ \\
& $(0.001)$ & $(0.001)$ \\
\hline Local authority: & & \\
Share of all UK employees & 0.11 & 0.23 \\
Mean log hourly wage diff & 0.127 & 0.174 \\
Wage Premium - $\widehat{\delta}_{A K M}$ & $0.023^{* * *}$ & $0.022^{* * *}$ \\
& $(0.002)$ & $(0.001)$ \\
\hline Public corp. E nationalised: & & 0.02 \\
Share of all UK employees & 0.04 & 0.262 \\
Mean log hourly wage diff & 0.009 & $0.167^{* * *}$ \\
Wage Premium - $\widehat{\delta}_{A K M}$ & $0.047^{* * *}$ & $(0.002)$ \\
\hline Non-profit serving hholds: & $(0.002)$ & 0.10 \\
Share of all UK employees & & 0.179 \\
Mean log hourly wage diff. & 0.06 & $0.019^{* * *}$ \\
Wage Premium - $\widehat{\delta}_{A K M}$ & 0.119 & $(0.002)$ \\
\hline
\end{tabular}

$£ 2002$. Standard errors (in parentheses) estimated robustly using person clusters;

${ }^{* * *}$ statistically significant at the $1 \%$ level, two-sided tests. 
FIGURE 1: Distribution of estimated firm fixed wage effects, $\widehat{\phi}_{j}$, by gender: employees in private or public sector jobs

(a) Male

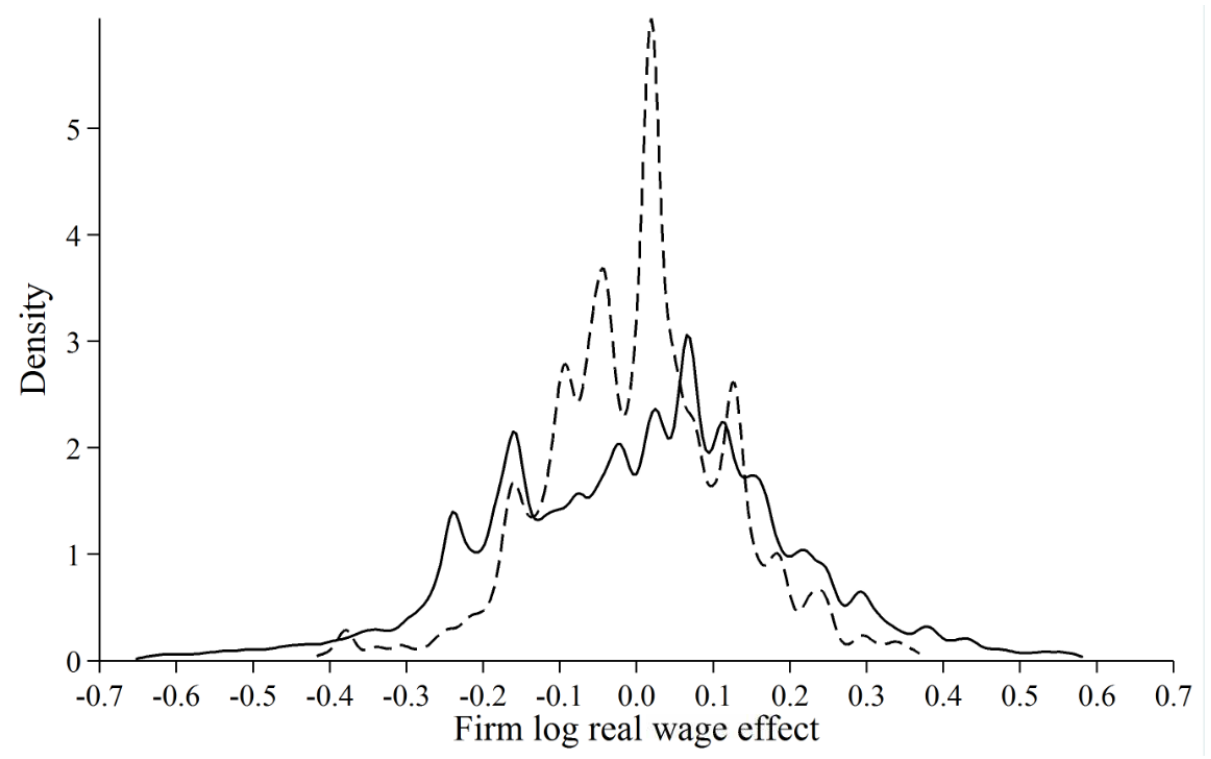

(b) Female

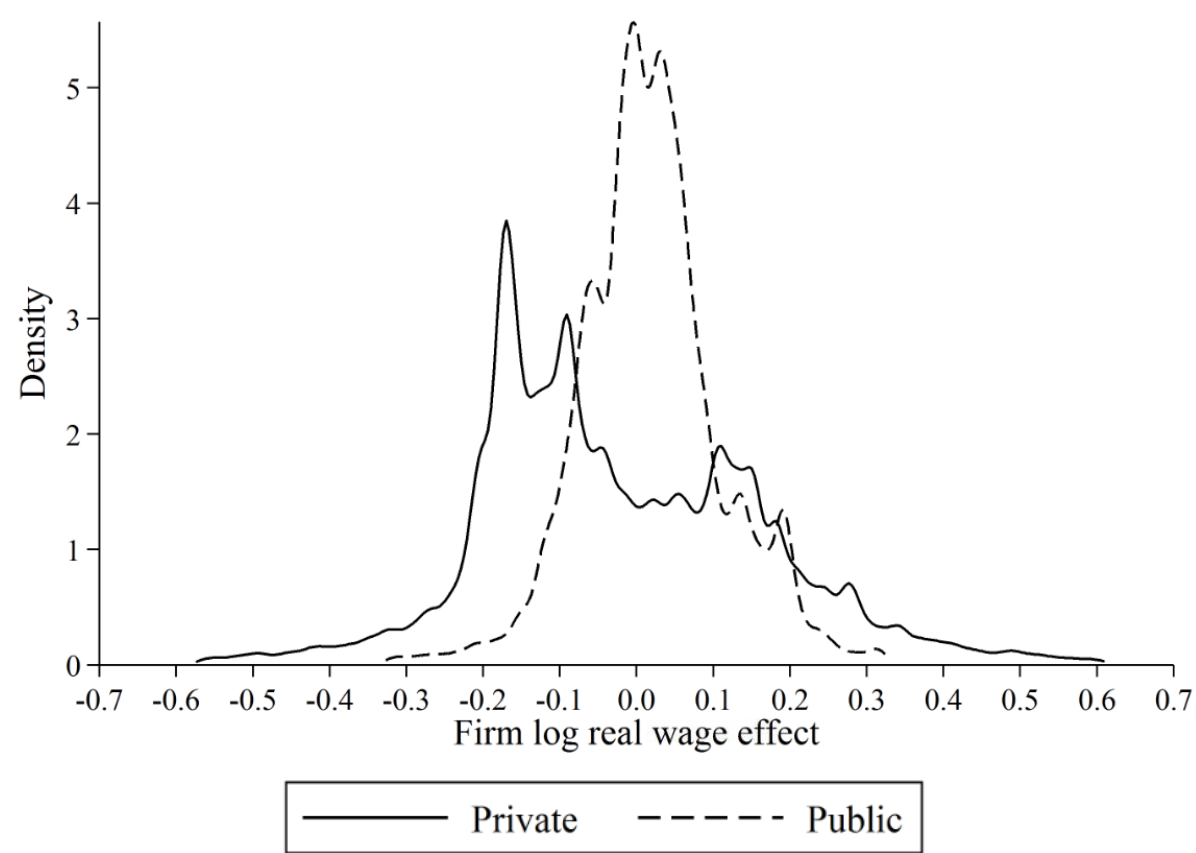

Notes.- kernel densities estimated with a bandwidth of one log point. Top and bottom $1 \%$ of firm effects by gender and sector not displayed. For each gender, the effects over public and private sector firms together have mean zero. 
FIGURE 2: Estimates of the UK public sector wage premium, 7-year rolling sub-periods

(a) Male

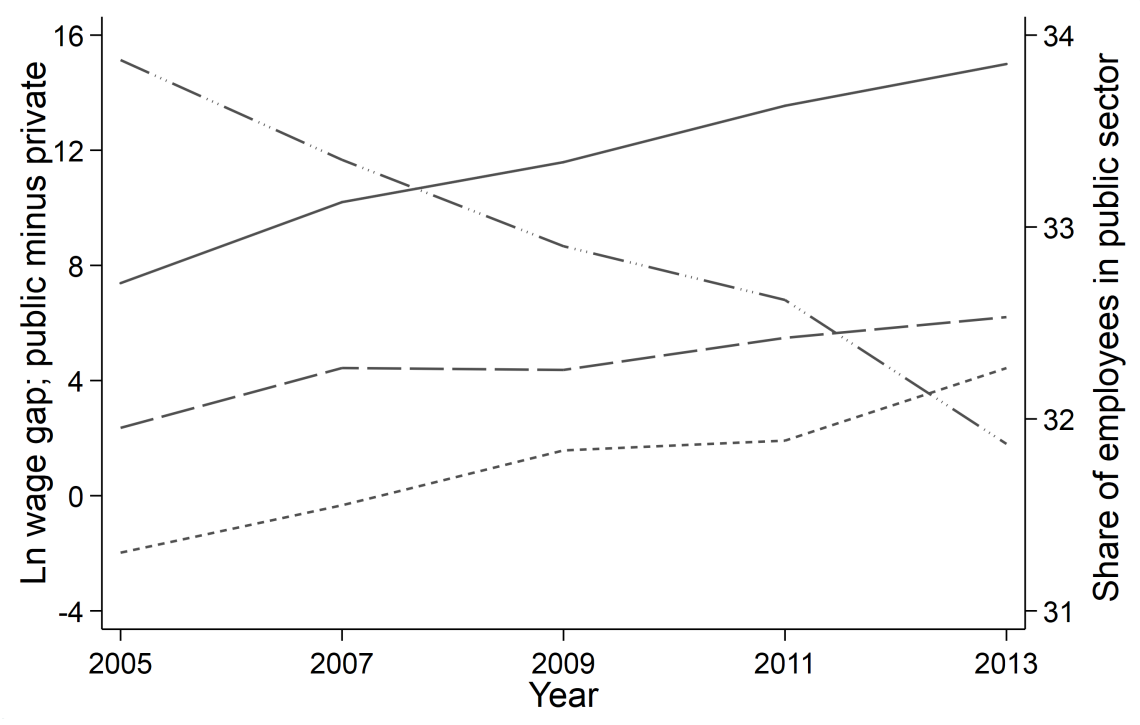

(b) Female

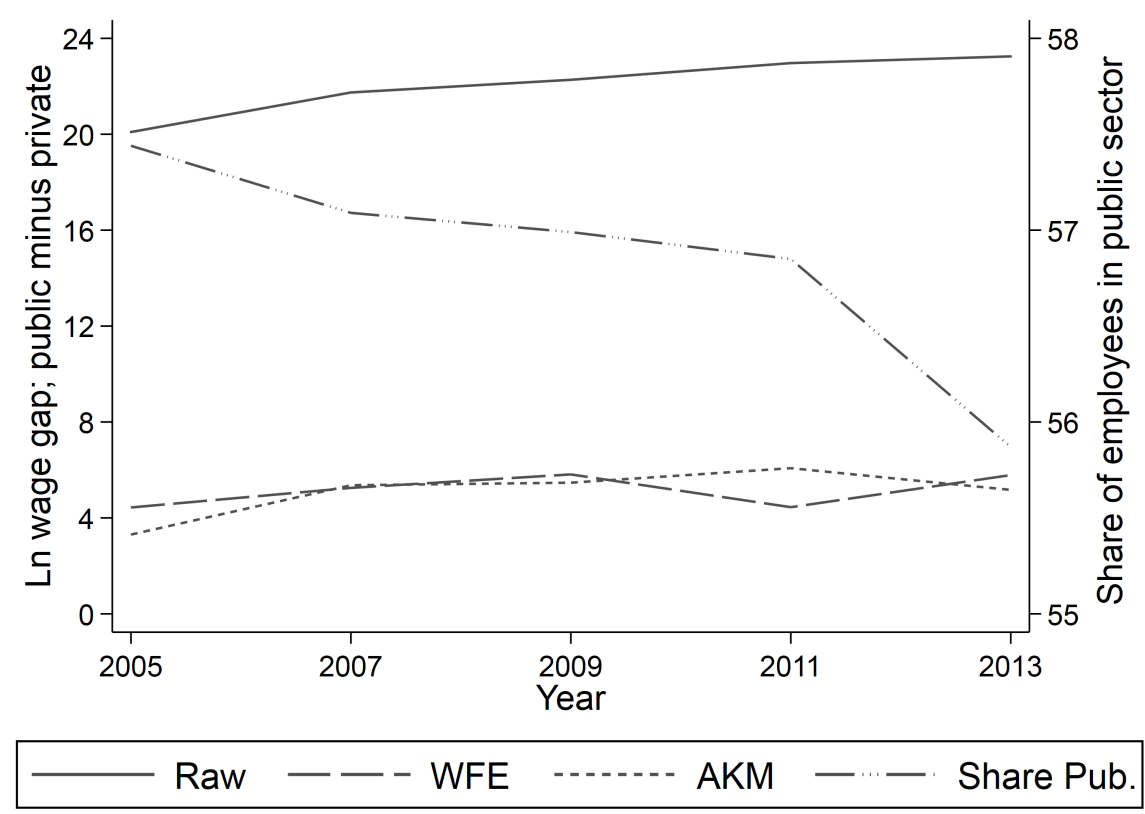

Notes.- 'Year' gives the mid-point of each estimation window. 'Raw' gives the sample mean wage premium. 'WFE' gives estimates from wage models with with worker fixed effects. 'AKM' refers to estimates from wage models with worker and firm fixed effects. 'Share Pub.' gives the share of sample employees in the public sector (right axis). 